\title{
Urban Heat Island Mitigation and Urban Planning: The Case of the Mexicali, B. C. Mexico
}

\author{
Jorge Villanueva-Solis \\ School of Architecture, Autonomous University of Coahuila, Coahuila, Mexico \\ Email: jorge.villanueva@uadec.edu.mx
}

How to cite this paper: Villanueva-Solis, J. (2017) Urban Heat Island Mitigation and Urban Planning: The Case of the Mexicali, B. C. Mexico. American Journal of Climate Change, 6, 22-39. https://doi.org/10.4236/ajcc.2017.61002

Received: October 10, 2016

Accepted: February 4, 2017

Published: February 7, 2017

Copyright $\odot 2017$ by author and Scientific Research Publishing Inc. This work is licensed under the Creative Commons Attribution International License (CC BY 4.0).

http://creativecommons.org/licenses/by/4.0/

(c) (i) Open Access

\begin{abstract}
The derivations of climate change on cities and their activities depend on their capacity for adaptation and mitigation. In this sense, it has long recognized the influence of cities on their own climate, which is typically warmer than the surrounding. This phenomenon called urban heat island (UHI) has a number of impacts on air quality, water demand and energy. Since the fourth IPCC assessment report indicates the need for urban centers devoting efforts to adaptation to reduce the risks of direct and indirect impacts of climate change. The same organization recognizes the urban planning as a tool to seek such order. However, it also recognizes that the current scale of climate models cannot provide a representation of urban areas. This paper explores the intensification of the UHI, its relationship with urban expansion and its impact on housing in the city of Mexicali, B.C. Its aim is to determine its impact and mitigation potential through analysis and modeling of urban structure, expressed in use and land cover, as well as the implementation of mitigation strategies. The results show on the one hand, the convenience of using dynamic modeling as a tool applied to urban planning with a focus on mitigation and adaptation to climate change. Furthermore, regarding the implementation of strategies, the results show that most efficiency is obtained when applied generally, this is, considering green and cool roofs, cool pavements and afforestation as part of urbanization process, otherwise, only partial results are achieved. Overall, housing land use has significant potential to mitigate the UHI in the city.
\end{abstract}

\section{Keywords}

Urban Heat Island, Mitigation, Adaptation, Dynamic Modelling, Urban Planning

\section{Introduction}

The urban expansion experienced by cities, is associated with numerous envi- 
ronmental problems, one of these is the Urban Heat Island (UHI). Defined as the temperature difference between the urban area and its surroundings, it is the result of two different but related processes; the first and most important, changes in land cover as a result of the urbanization process that transforms materials with impervious surfaces such as asphalt and concrete. The second refers to activities in the city mainly transport and industry due to thermal emissions that contribute to urban heating [1]. The issue is increasingly important because of the global trend towards urbanization and sprawl of cities, also because the UHI has direct implications for air quality, public health, energy management and urban planning. Reasons why this issue has become one of the major environmental challenges related to the urbanization process, since the temperature rise associated with UHI tends to exacerbate the problems are mentioned above [2]. Besides, it is on the core issues identified when the issue of mitigation and adaptation to climate change is approached from an urban focus.

Currently, most studies on UHI have taken place in densely populated cities, located in temperate and subtropical climates [3]. In contrast, cities located in desert ecosystems have been studied very little [4]. Such studies are even scarcer for the deserts of North America having extreme aridity, with the exception of cities like Las Vegas, Phoenix and Tucson in the United States [5]-[10] and more recently in the city of Mexicali in Baja California, Mexico [11] [12] [13]. Overall, the researches on the subject have mainly focused on the identification and analysis of the thermal behavior within urban areas, and the establishment of mitigation strategies. In this regard, Akbari establishes the principal strategies to mitigate the effects of the UHI, increasing the Albedo roofs and floors, and urban reforestation [14].

However, addressing the issue of ICU mitigation and adaptation in the urban planning process is limited only to the definition of strategies, which demonstrates the relevance of integrating strategies into the planning process. In this sense, this research determines the potential of the current urban structure of the city to implement those strategies. The proposed method was developed in a simulation context, considering the current and future spatial organization of the city, also land cover and type of buildings.

The Valley of Mexicali, in Baja California (Mexico), located at $32^{\circ} 38^{\prime}$ north and $115^{\circ} 20^{\prime}$ west, has the distinction of being a border region contiguous with the State of California in the United States. The whole region belongs to the Physiographic Province of the Sub Colorado River Delta in the Sonoran Desert. As a result, the region has a very arid climate, only $75 \mathrm{~mm}$ of annual rainfall and extreme temperature conditions: maximum temperatures exceeded $50^{\circ} \mathrm{C}$ in summer and minimum temperatures below $0^{\circ} \mathrm{C}$ in the winter.

Mexicali founded in the early twentieth century on a floodplain, which contributes to heat transfer, is very uniform. The census of 2010 states the city covers an area of 14,890 hectares and has a population of 689.775 inhabitants, resulting in a density of 46 inhabitants per hectare, showing a city expansion horizontal. The urban fabric is organized into six zones; this characterizes the spaces of the city from the functional point of view and land use. The distribution of 
land use is predominantly residential with $56 \%$, industrial use accounts for $7 \%$ and the commercial and services $6 \%$, meanwhile the use intended for urban facilities (that includes public parks, schools and other public buildings) corresponds to $8 \%$ of the urban area, in terms of conservation only $1 \%$; another important use is for streets and infrastructure that covers $15 \%$ of the city, and the remaining seven percent is for mixed use (commerce-services-industry).

In the last three decades, the city underwent a demographic and economic boom due to growth in manufacturing currently has eleven industrial parks with a total of 1164 manufacturing firms, using 825 hectares of urban land; most of these industrial parks were built in the 1980s in what used to be farmland on the outside of the city. However, the expansion of the city in the following decades caused the industry will be immersed in the city; situation that caused that industrial buildings contribute to increased temperature by their construction characteristics and their emissions [15] [16] [17].

In contrast, the city has about 140 hectares of public green areas, surface representing an allocation of $2.1 \mathrm{~m}^{2}$ per inhabitant, while the national legislation provides $10 \mathrm{~m}^{2}$ per inhabitant and the World Health Organization sets $9 \mathrm{~m}^{2}$ per inhabitant; therefore, there is a significant deficit [18]. Accordingly, it can be seen that the effects of urban areas with high thermal emission are spread throughout the city. In contrast, areas of low thermal emission or thermal sinks represent a minimum area compared to other land-use.

\subsection{Study on the Urban Heat Island}

The first approach to the UHI of the city took place in 1996 through a study using satellite images (NOAA AVHRR), the results of this study show a series of islets high thermal emission matching the industrial, commerce and service, which are areas of high degree of urbanization in the city [19]. Later García-Cuetousing NOAA AVHRR and Landsat ETM+ images and air temperature measures, analyzed atmospheric and surface UHI and its relation to land use. The results confirm the existence of a surface UHI by comparing the city with its surroundings, as well as identifying important thermal contrasts within the city and the development of a night UHI [13]. The largest temperature contrasts are observed in this study with greater than $40^{\circ} \mathrm{C}$ between the urban area and the surrounding agricultural area values, that in the months of July and August. Two years later, the same author using a database from 1950 to 2000, in temporary and spatial analysis of the air temperature in the urban canopy of the city and its surroundings; in this study, it was demonstrated the presence of a mass of warm night air in urban air, where the maximum difference between the city and its surroundings occurs in winter with a value of $5.7^{\circ} \mathrm{C}$ [12].

\subsection{Mitigation of Urban Heat Island}

The main mitigation strategies are: reforestation, green and cool roofs and cool pavements. Its application reduce the effect of the UHI, also saves energy and greenhouse gas emissions are reduced, contribute to reducing risks to public health, without forget the aesthetic value of the urban green spaces. So these 
strategies must become essential components of the current process and future development. This requires assessing the city and its planning instruments through the relations between land use, land cover and surface temperatures. Detailed analysis of these interactions allowed an approach to the first urban planning schemes with a focus on climate change adaptation.

Increase green spaces inside the city are an important mitigation measure [20] [21]. In addition to functioning as a filter against the wind currents, also intercepting solar radiation before being absorbed by the impervious materials of the city, helping to reduce the air temperature between $1.6^{\circ} \mathrm{C}$ and $3.3^{\circ} \mathrm{C}$ by evapotranspiration (Meredith, 2004). At the same time, vegetated areas contribute to groundwater recharge and with evapotranspiration controls the rise of surface temperature, which also happens in the case of green roofs [22].

Meanwhile fresh or reflective roofs are those using materials that have two important properties a high albedo and emissivity or thermal emittance. Both strategies are identified as the most effective to mitigate the UHI [23]. Increase the albedo on roofs as a mitigation strategy is important, given the size of the city that corresponds to the roofs; therefore, it is logical to consider options for reducing the thermal load on them. For example, an increase in the albedo 0.07 on surfaces of buildings and roads can decrease by up to $2^{\circ} \mathrm{C}$ ambient temperature [24] [25]. Estimates indicate that by reducing the solar radiation absorbed by roads and parking lots from $90 \%$ to $65 \%$ the peak air temperature can decrease by $0.6^{\circ} \mathrm{C}[26]$.

Green roofs refer to the roofs with vegetation, which provide shade and reduce the temperature of the surrounding air through evapotranspiration; besides reducing the thermal load of the building. Another advantage observed in green roofs is their property of thermal mass, because the inner surface temperature is increased after time compared to the other surfaces.

\section{Method and Information}

The methodological framework proposed has two main components; the first one relies on the use of digital satellite images particularly the Lands at thermal infrared band which provides clear information on the thermal variation, allowing having timely information and temporary ground cover and thermal behavior within the urban space. The temperature values obtained from the infrared band, were used to establish the thermal characteristics within the city, its distribution and future conditions of the UHI, these were calculated based on the different variants of urban fabric including the potential of mitigation, which results in urban planning measures that can be evaluated in a simulation environment.

As a second component, dynamic modeling and simulation of scenarios were used to analyze the process of transformation and growth of urban space, also to assess the appropriateness and effectiveness of mitigation strategies-adaptation to the UHI. Other authors state that numerical simulation models are useful in assessing mitigation scenarios of UHI, the use of these models allows evaluate 
different scenarios quickly, making this tool a favorite in urban climatology [5] [27].

Based on the above and given that the urban fabric can be synthesized as a heterogeneous space composed of a variety of materials and surfaces, which when exposed to sunlight heat up and these in turn heat the air that surrounds them. The dynamic model developed is configured through the structure of the urban fabric (land use and land cover), parameters that affect the temperature of the city and translates into suitable variables to be treated in simulation context. In synthesis, remote sensing was used to know the characteristics of urban space, including its thermal behavior; and dynamic simulation to know changing conditions of the urban fabric in relation to the use and land cover and its influence on temperature of the city.

\subsection{Expansion, Characterization and Analysis of Urban Space}

Mexicali's urban expansion over the past three decades shows an example of an urban model without restriction; in this period the city grew 11494.28 hectares, an average of 387 hectares per year, this represents $77 \%$ of the current urban area. The urban development plan indicates that in the period 1998 to 2004 the urban area increased $39 \%$ and the occupancy just $22 \%$, doubling the vacant area from $12 \%$ to $28 \%$. Table 1 shows the dynamic expansion of the city in different periods [28].

As shown, the expansion of the city is heightened from the 1980s with an occupation of 9888.11 hectares, corresponding to $57 \%$ of the total area of the present city. The pattern of expansion had the following characteristics: to the south middle income housing developments, eastward middle and high income housing; and to the west and southwest low income housing [28].

As a result of the urban expansion, the mix of housing and industrial activity worsened, also the lack of infrastructure and urban services worsened, causing potential hazards and conflict situations for the resident. Thus showing an incipient degree of integration of the city, a low land use and a distribution of the population to the periphery of the city far from the areas of employment [29].

Table 1. Territorial expansion of Mexicali.

\begin{tabular}{ccc}
\hline Periods & Area (hectares) & $\%$ \\
$1900-1920$ & 501.86 & $3 \%$ \\
$1920-1940$ & 792.46 & $5 \%$ \\
$1940-1960$ & 2077.00 & $24 \%$ \\
$1960-1980$ & 4219.57 & $32 \%$ \\
$1980-1998$ & 5558.96 & $25 \%$ \\
$1998-2010$ & 4329.15 & $100 \%$ \\
\hline
\end{tabular}

Source: Municipal planning institute of Mexicali. 
The current city limits are defined by three major areas located to the periphery. The First One is located southeast of the city known as Nuevo Mexicali, as is shown in Figure 1, where the social interest housing complexes, industrial parks, shopping centers and services predominate; in this side of the city is where the new U.S. border crossing is located. The Second Zone at the south of the city, near the Mexico and Xochimilco lagoons, where the predominant buildings are progressive and popular social housing with limitations in the provision of infrastructure and public services. Finally, the Third Zone is located to the west, aimed at developing progressive popular housing developments and some social interest housing and industrial parks. Like the previous area, it has limitations in providing infrastructure, trade and services [30].

The relationship between land cover, land use and thermal behavior, is approached by the microclimate relationship expressed by the UHI (as result of the thermal differences between artificial surfaces like pavements and roofs, and green spaces and water bodies).

The following image (Figure 2) shows the formation of the UHI obtained from a Landsat 8 in June 2013 image, it can be seen as the urban fabric of Mexicali contrasts with its surroundings by high surface temperatures, can also be identified the main city park (interurban green space) or the sports city park and the university campus they presents significant temperature contrasts with the rest of the city.

Generally can be identified four main ranges of surface temperatures inside the city, the first one between 27 and 34 Celsius degrees which represents 1.2

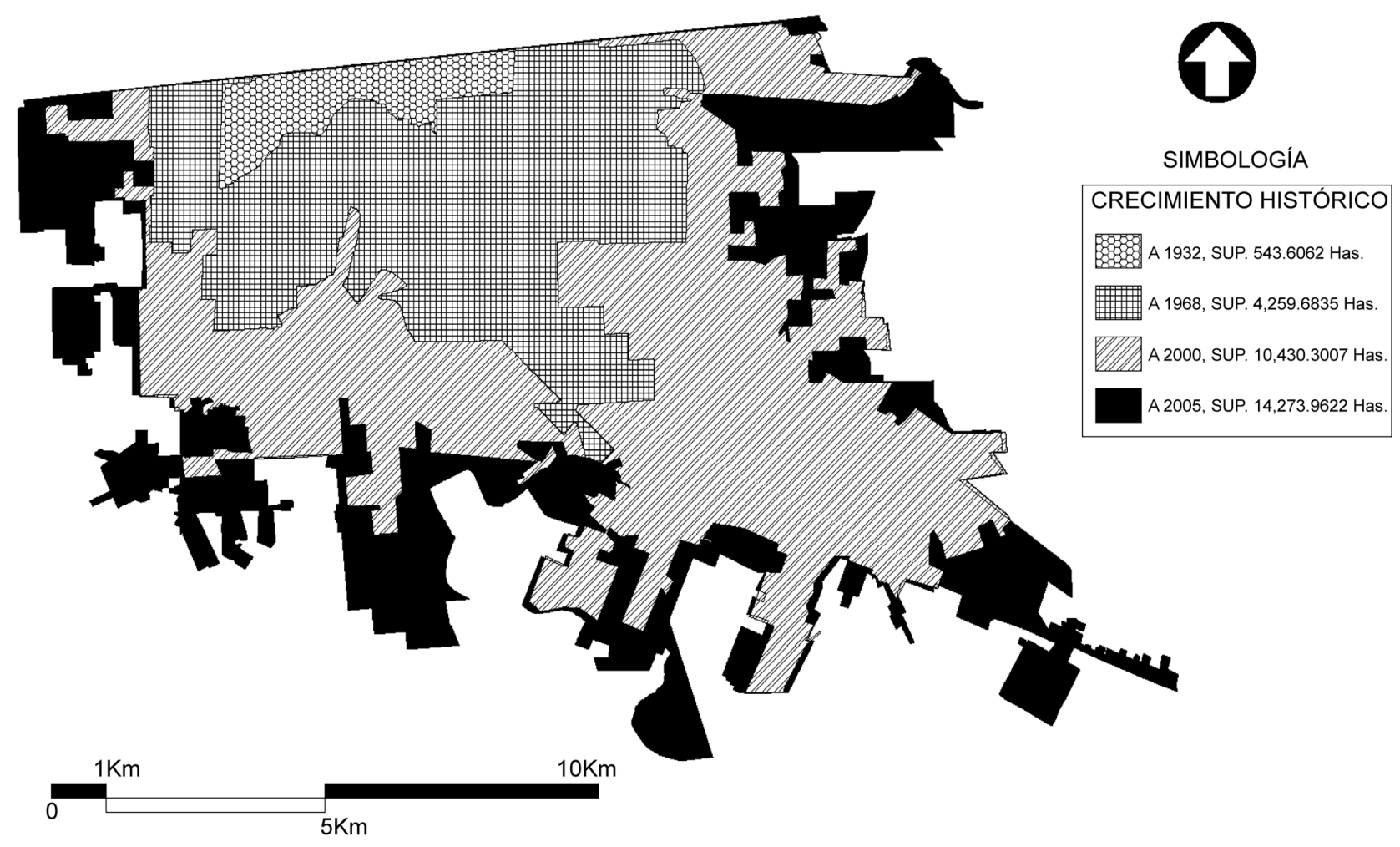

Figure 1. Stages of territorial expansion. Source: Municipal planning institute of Mexicali. 
percent of the urban space, basically it refers to the heat sink into the city; the range of $35-41$ degrees represents 13 percent of the urban area, the following range between 42 and 46 degrees covers 84 percent of the city, show an homogeneous composition of the urban fabric resulting in a distribution of high temperatures, finally, the range of 47 to 50 represents 1.8 percent of the urban space, and clearly identified in the industrial, commerce and services areas. It is shown in Table 2.

The distribution of land use in the city predominates housing with $57 \%$, followed by industrial use, commerce and services with $6 \%$ and the urban facilities with $6 \%$ too, this one exclude the public green spaces that represents only $2 \%$; the mixed use (storage, industrial and commercial services) accounts for 5\%, meanwhile the intended for conservation represent only one percent.

In general, we can observe that the urban development plan sets the stage for urban expansion, when considering a $210 \%$ to 2025 with an average annual growth rate of $10 \%$ for each land use (Table 3). This shows that the current model of urban planning encourages urban sprawl spreads, as opposed to the current urban theory that pursues sustainability in compact urban environments.

As part of the land cover analysis, two procedures performed, the first one, aimed to characterize the urban space using the following characteristics: common roofs; metal roofs; asphalt; bare soil (vacant land) and green spaces. The

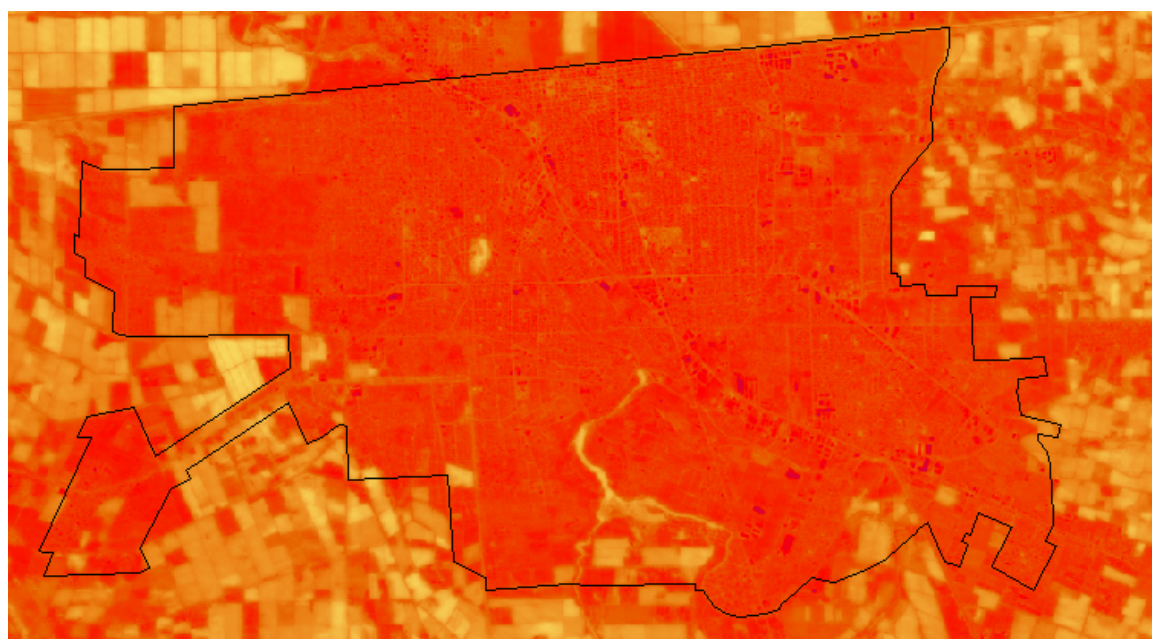

Figure 2. UHI of Mexicali based on Landsat 8 images.

Table 2. Surface temperature ranges within the city.

\begin{tabular}{cc}
\hline Surface Temperature & Coverage in the City \\
\hline Range $27-34\left({ }^{\circ} \mathrm{C}\right)$ & $1.2 \%$ \\
Range $35-41\left({ }^{\circ} \mathrm{C}\right)$ & $13 \%$ \\
Range $42-46\left({ }^{\circ} \mathrm{C}\right)$ & $84 \%$ \\
Range $47-50\left({ }^{\circ} \mathrm{C}\right)$ & $1.8 \%$ \\
\hline
\end{tabular}


Table 4 shows the summary of the results, as show over $70 \%$ of urban space is covered by roofs and only $4.9 \%$ have a plant cover.

The second procedure was performed with the objective of having more information on vegetation cover in the city, for it was used the normalized difference vegetation index (NDVI) (Figure 3), like the previous characterization was used a Lands at 8 image. The results found that the surface covered with vegetation in the city is higher than that identified with the supervised classification, because the NDVI identified small green spaces like: private gardens and street vegetation.

To know more about the distribution of green spaces and its relationship with the land use, was established an indicator that relates both variables to define the green patterns of the city. The NDVI results show that residential areas are those with more green area with $70.8 \%$ as a result of including private gardens, followed by urban facilities with $16.9 \%$ in which the public green spaces are included. It is important to highlight the low vegetation cover for industry, commerce and services; which generate higher thermal emissions. It is shown in $\mathrm{Ta}$ ble 5 .

Furthermore, by comparing the results of the NDVI with the UHI, we found that only the consolidated green spaces have an impact on the surrounding

Table 3. Land use and land reserve to year 2025.

\begin{tabular}{ccccc}
\hline Land Use & 2004 & $\%$ & 2025 & Reserve to 2025 \\
Housing & 8452 & $56.86 \%$ & 17,501 & 9049 \\
Commerce \& Services & 821 & $5.52 \%$ & 1969 & 1148 \\
Industrial & 900 & $6.06 \%$ & 2188 & 1287 \\
Urban Facilities & 909 & $6.11 \%$ & 1787 & 878 \\
Green Spaces & 299 & $2.01 \%$ & 588 & 289 \\
Infraestructure & 91 & $0.61 \%$ & 176 & 85 \\
Vialidades Principales & 2415 & $16.25 \%$ & 4668 & 2252 \\
Mixed (Storage, Commerce \& Industrial) & 794 & $5.34 \%$ & 2063 & 1268 \\
Conservation & 184 & $1.24 \%$ & 313 & 128 \\
Total = & 14,866 & $100 \%$ & 31,251 & 16,386
\end{tabular}

Table 4. Land covers characteristics.

\begin{tabular}{ccc}
\hline Land Cover & Area & $\%$ \\
\hline Common Roofs & 13218.30 & $64.1 \%$ \\
Metal Roofs & 1416.60 & $6.9 \%$ \\
Asphalt & 2106.36 & $10.2 \%$ \\
Bare Soil & 2863.17 & $13.9 \%$ \\
Green Space & 1003.05 & $4.9 \%$ \\
Total $=$ & 20607.48 & $100.0 \%$
\end{tabular}




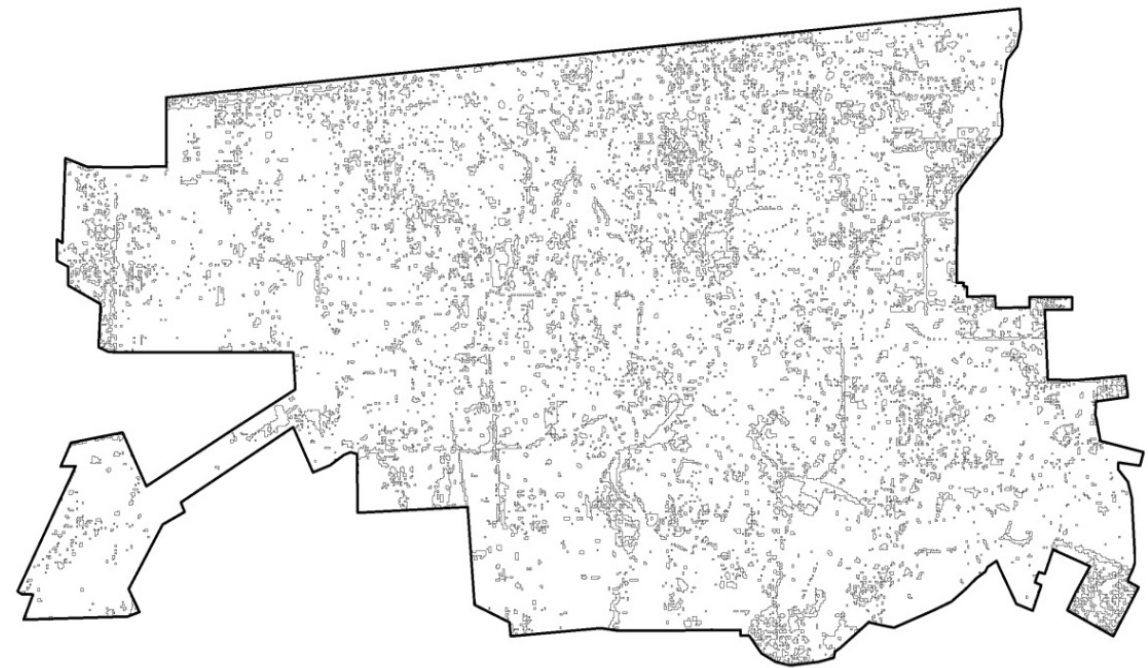

Figure 3. NDVI characterization.

Table 5. NDVI and land use coverage.

\begin{tabular}{ccc}
\hline Land Use & Area & $\%$ \\
\hline Housing & 754.5926 & 70.8 \\
Commerce \& Services & 87.5410 & 8.2 \\
Industrial & 28.0698 & 2.6 \\
Urban Facilities & 180.0590 & 16.9 \\
Mixed & 14.8699 & 1.4 \\
Total $=$ & 1065.1323 & $100.0 \%$ \\
\hline
\end{tabular}

temperature (heat sinks), this allows us to anticipate the final strategies and establish that consolidated green spaces (such as urban parks) have a considerable environmental service in terms of mitigation and adaptation to the UHI.

In addition to the above, other studies such as those referred to by PericoAgudelo [31] in cities of Canada and the United States have shown that the urbanization process modifies the thermal characteristics of the city, because the urban morphology in conjunction with artificial surfaces becomes heat collectors.

\subsection{Construction of Mitigation-Adaptation Scenarios}

Focused on the implementation of the strategies (green and cool roofs, cool pavements and afforestation) and its relation to land use, are the guidelines followed to construct the mitigation and adaptation scenarios to 2030. In terms of urban development means that it should be included systematically the strategies in current and future buildings and in the development works (Table 6 and Table 7). This way of constructing scenarios allows us to evaluate the effectiveness of each strategy in each land use and thus an outline of what could be a series of urban public policies. 
Table 6. Mitigation scenario based land use.

\begin{tabular}{cccccc}
\hline \multirow{2}{*}{ Land Use } & \multicolumn{5}{c}{ Escenario } \\
\cline { 2 - 6 } & 2010 & 2015 & 2020 & 2025 & 2030 \\
\hline Housing & $0 \%$ & $25 \%$ & $50 \%$ & $75 \%$ & $100 \%$ \\
Industrial & $0 \%$ & $25 \%$ & $50 \%$ & $75 \%$ & $100 \%$ \\
Urban Facilities & $0 \%$ & $25 \%$ & $50 \%$ & $75 \%$ & $100 \%$ \\
Commerce \& Service & $0 \%$ & $25 \%$ & $50 \%$ & $75 \%$ & $100 \%$ \\
Mixed & $0 \%$ & $25 \%$ & $50 \%$ & $75 \%$ & $100 \%$ \\
\hline
\end{tabular}

Table 7. Mitigation scenario based adaptation strategy.

\begin{tabular}{cccccc}
\hline \multirow{2}{*}{ Strategy } & \multicolumn{5}{c}{ Escenario } \\
\cline { 2 - 5 } & 2010 & 2015 & 2020 & 2025 & 2030 \\
\hline Green roofs & $0 \%$ & $25 \%$ & $50 \%$ & $75 \%$ & $100 \%$ \\
Cool roofs & $0 \%$ & $25 \%$ & $50 \%$ & $75 \%$ & $100 \%$ \\
Porous pavements & $0 \%$ & $25 \%$ & $50 \%$ & $75 \%$ & $100 \%$ \\
Cool pavements & $0 \%$ & $25 \%$ & $50 \%$ & $75 \%$ & $100 \%$ \\
Afforestation & $0 \%$ & $25 \%$ & $50 \%$ & $75 \%$ & $100 \%$ \\
\hline
\end{tabular}

The scenarios were simulated in STELLA ${ }^{\oplus}$ through a model that uses the characteristics of coverage and land use in the city. This allows us to estimate the surface temperature under different land cover as follows:

$$
\begin{aligned}
& \text { Tvegetation } \times \text { Avegetation }+ \text { Tpavements } \times \text { Apavements } \\
& + \text { Troofs } \times \text { Aroofs }+ \text { Tmisc } \times \text { Amisc }
\end{aligned}
$$

where, $T$ is the temperature and $A$ is the fraction of the total area. Thus surfaces covered with vegetation present a surface temperature of $27^{\circ} \mathrm{C}$; those covered with cool pavement of $38^{\circ} \mathrm{C}$; meanwhile cool roofs present temperatures of $35^{\circ} \mathrm{C}$, and green roofs of $29^{\circ} \mathrm{C}$. The profile of the UHI depends on how the air is heated by the different surfaces of city, using cool coatings or vegetation allows decreasing surface temperatures, having positive effects on the temperature of the city.

The purpose of the model is to simulate the possibilities of mitigation and adaptation of the current and future urban fabric under the aforementioned parameters, its main structure has the following elements:

- Land use and land cover,

- UHI mitigation strategies,

- Local climate change scenarios [32],

- Temperature increase by UHI [33],

- Temperature balance in relation to the use and land cover (focused on implementing strategies).

\section{Results}

Before showing the results, it is important to remember the purpose of the 
paper; this was directed to explore the incorporation of mitigation strategies in to the city planning process. The following graphics show the simulation results under the visions described in the construction of mitigation and adaptation scenarios. The first graphic (Figure 4) show the potential of mitigation-adaptation by land use, the performance of each strategy is also noted. Later, Figure 5

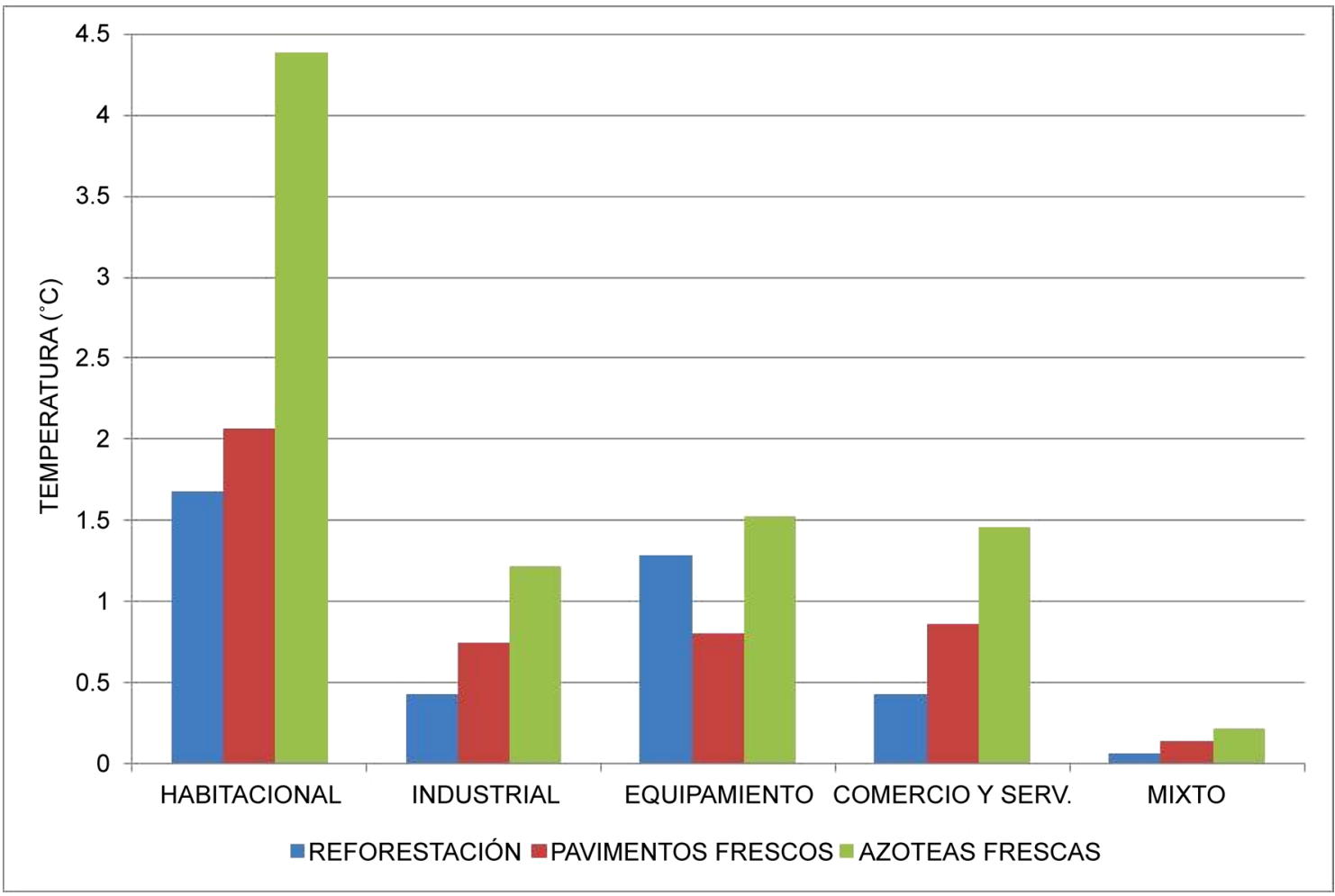

Figure 4. Mitigation and adaptation potential by land use.

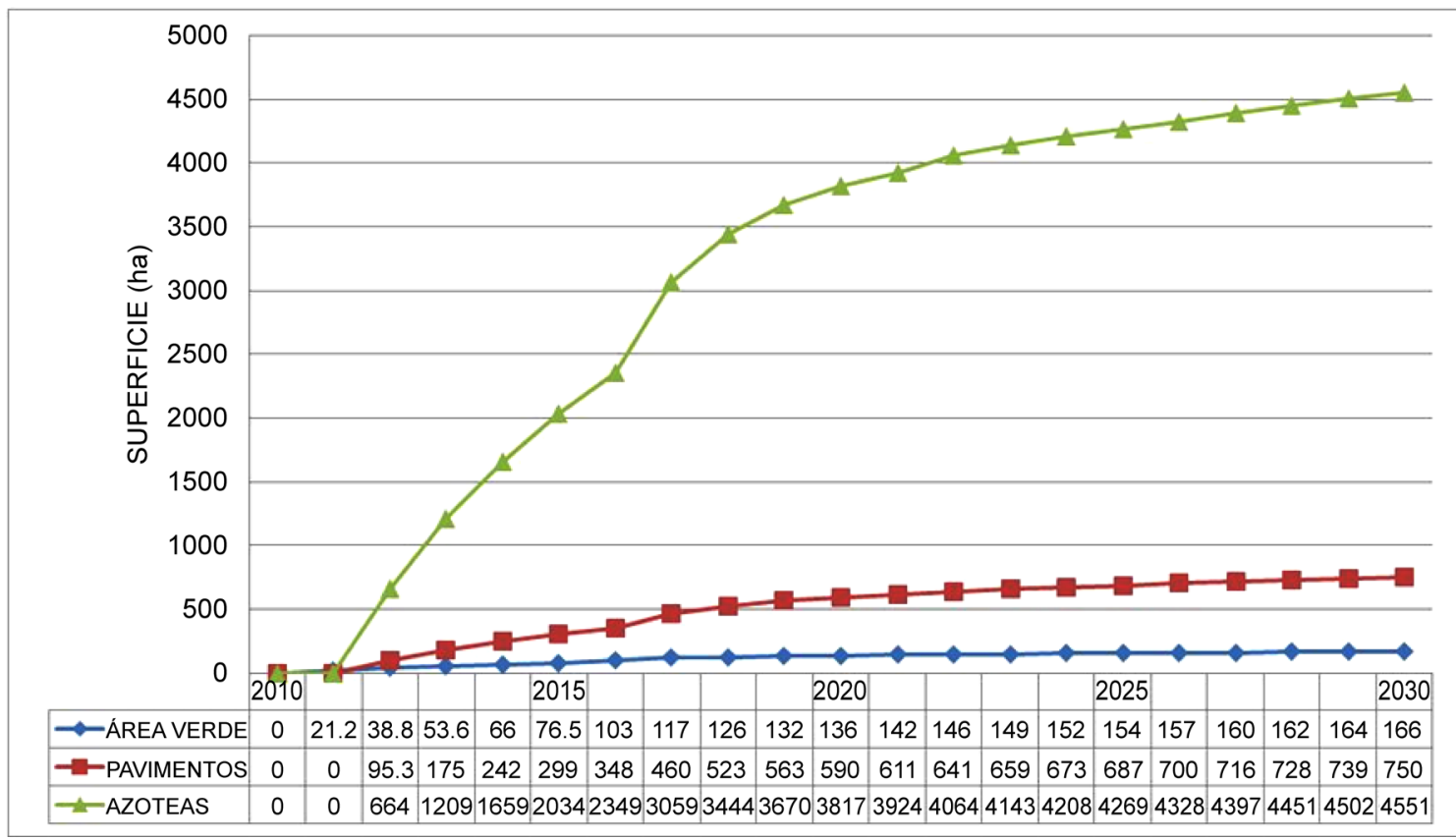

Figure 5. Relation of urban expansion and potential area for mitigation. 
shows the relationship between urban expansion and adaptation potential; meanwhile Figure 6 shows the temporal relationship in applying strategies, ultimately Figure 7 shows the relationship between urban expansion and adaptation temperature.

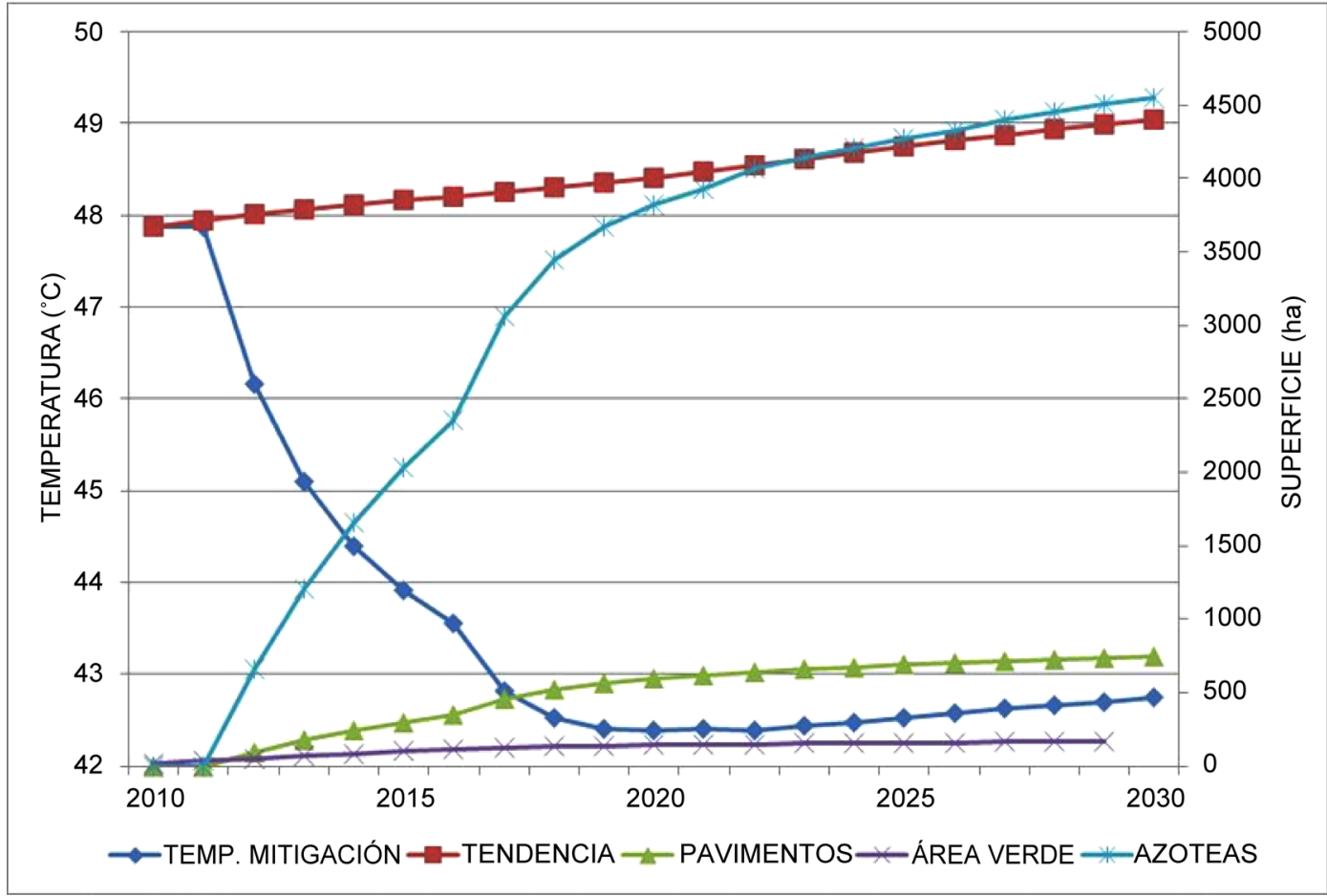

Figure 6. Temporal relationship of implementing strategies.

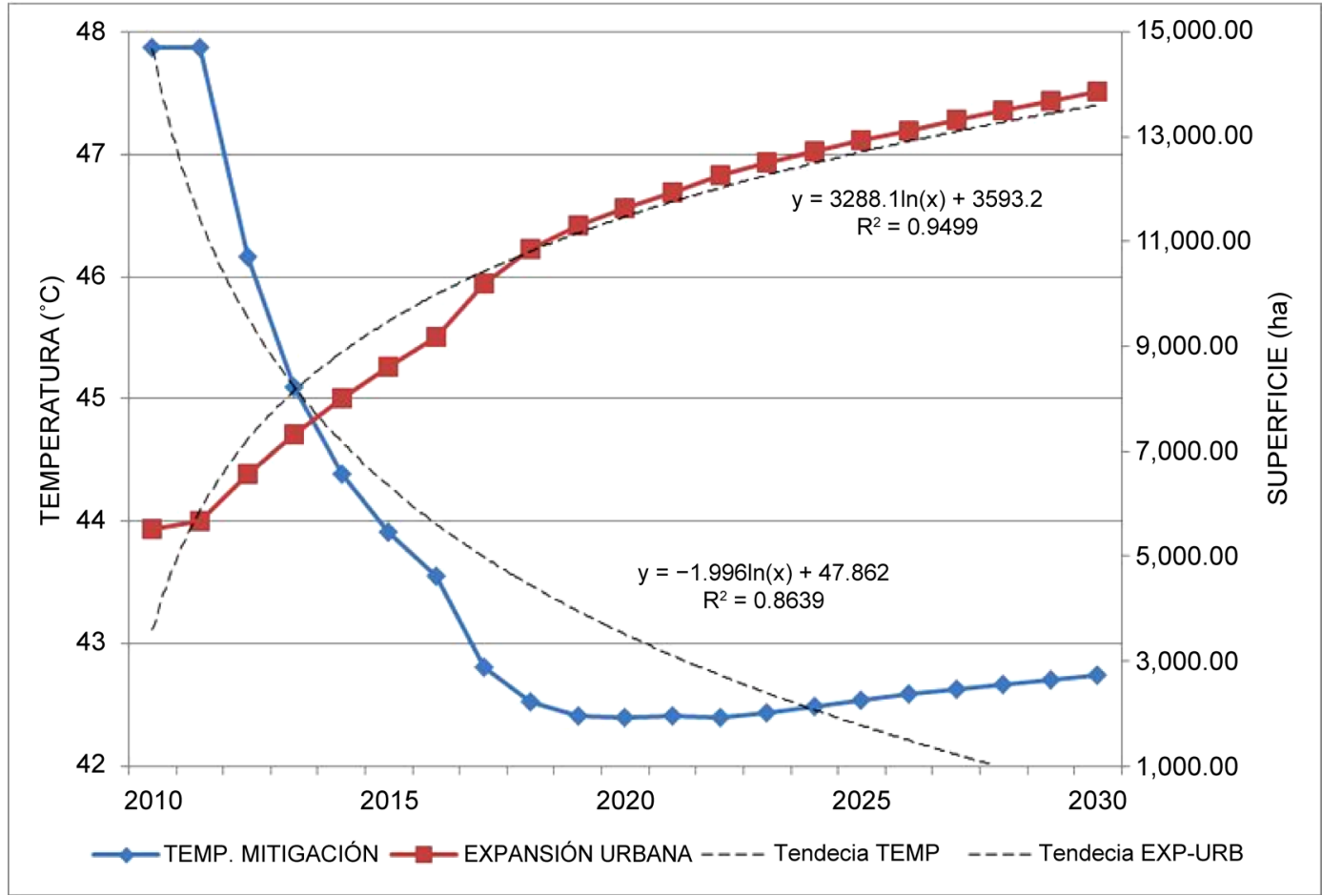

Figure 7. Relationship between urban expansion and temperature of mitigation-adaptation. 
Figure 4 shows the mitigation potential of each land use. At the same time, it shows that strategies oriented to roofs are the most effective; they follow the strategies on pavements and finally trees and vegetation cover. Another reading to the above is that the surface of roofs of housing are much higher than those of buildings for mixed use, while the surface of roofs of buildings of urban facilities are very similar to those for trade and services.

The following graphics, shows on the one hand the UHI temperature trend values and the mitigation-adaptation results, and on the other, the amount of space used by strategy. The first thing to note, is the difference between the temperature of mitigation-adaptation and the trend towards intensification which exceeds six degrees; further, the important effect obtained from the beginning to 2019, then the temperature was stabilized until 2023 when has a slight tendency to rise. This has some overlap with the curve of roofs and pavements which also have a period of stability. It should be noted, as a result of simulation it is from 2020 when $50 \%$ of the applied potential strategies; therefore, the behavior of the curve shows that is the first half when implementing strategies is most effective.

Meanwhile the previous graphic, warns the direct relationship between urban expansion (including potential and non-potential) and adaptation temperature. Therefore, it can be considered even the urban expansion trend the city can achieve lower the UHI.

\subsection{Urban Planning, Mitigation and Adaptation to the UHI}

Integrate UHI mitigation and adaptation as part of the urban planning process is an ongoing challenge, for this reason it must be consider the importance of mitigation in the current situation and secondly, how mitigation actions can be transformed into future adaptation strategies to be incorporated into the instruments for manage urban development.

In such a way, the issue of mitigation-adaptation of the UHI is articulated with the urban development policy instruments, allowing incorporate the issue in the urban agenda and its associated instruments, which in the case of Mexicali ranging from the city's urban development plan to construction regulations. Also reveals the need to think in an integrated way, combining physical aspects of the environment with economic development issues and social welfare, especially in terms of vulnerability and climate resilience. In this sense, mitigate and adapt the urban space to the UHI and climate change in generally is critical in terms of sustainable development; therefore, the actions will be in the medium and long term due to its complexity.

In contrast, the main mitigation strategies: cool roofs, cool pavements and green spaces, are far from being a standard practice for urban development and construction in the city. For example, cool roofs (referring to the reflective) are identified in recent industrial buildings or warehouses which use sheet steel roofs; meanwhile, cool pavements (outside of some new concrete streets) are virtually nonexistent, all streets and parking lots were made with asphalt. In 
terms of green spaces, it is clear that there are fewer due to lack of maintenance.

\subsection{Integration of the Results into the Planning Process}

According to the above and as an outline of how to integrate the research results into the process of urban planning. The following general criteria are established for their integration.

When considering how significant is the $54 \%$ of the roofs area in housing (Figure 8) allows us to observe that continuing with the same housing policy, their roofs should have one of the two strategies (green or reflective roofs). The influence of housing is similar to establish a policy for each of the remaining uses. This without downplaying the impacts generated by other land uses, as mentioned the industrial, commerce and services sector is where more the UHI intensified.

Similarly happens in pavements, housing land use is the most representative, allowing porous pavements (light traffic) as concrete pavements (heavy traffic on main streets). Very similar to the previous strategy, the sum of the rest of the land uses generates the same positive impact like housing use (Figure 9). However the issue of paving on the other land uses has other considerations, like high traffic, which suggests that the only option for them is concrete.

Meanwhile green spaces offers different modes to be implemented, on one side, housing represents $44 \%$ of the potential, on the other side, urban facilities represents $33 \%$ (Figure 10). Both represent more than $75 \%$ of the city potential, without underestimate the potential of other uses. However, the literature on the subject states that a largest the green space will be more effective as a mitigation strategy; hence the importance of green spaces for housing (from private gardens to neighborhood parks). In the case of urban facilities, especially those close to housing such as schools and community centers are important because together form heat sinks.

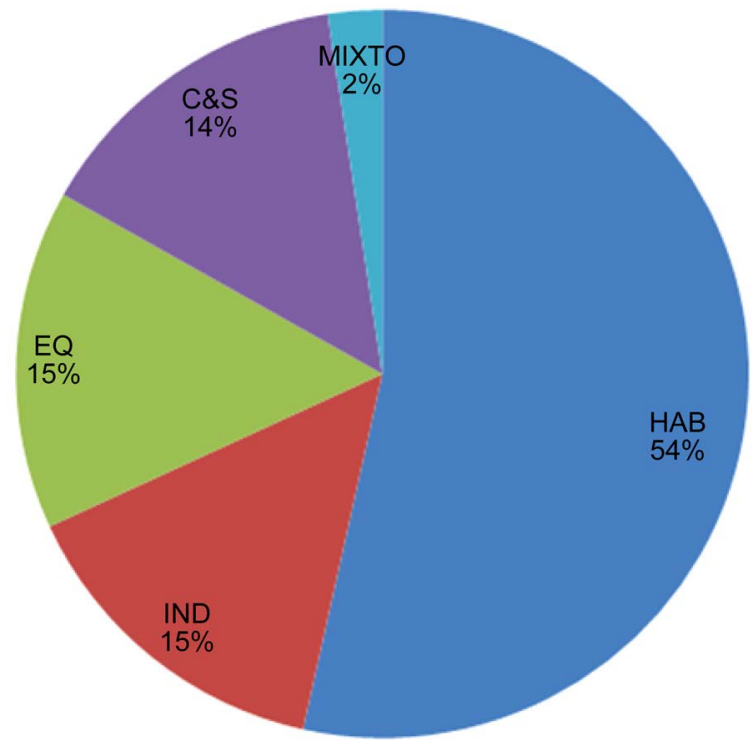

Figure 8. Roofs strategy potential by land use to year 2030 . 


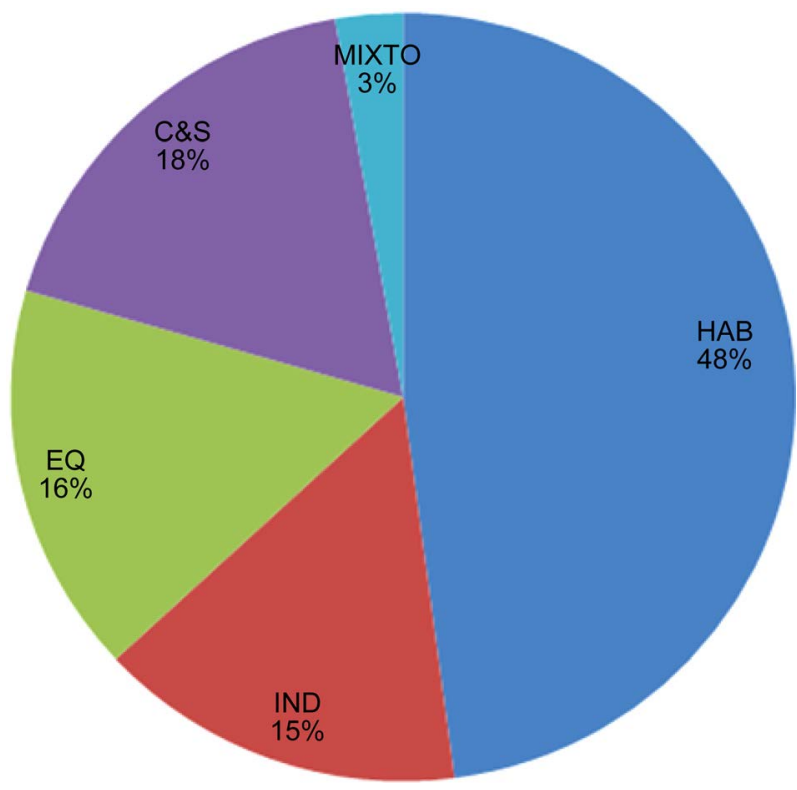

Figure 9. Pavements strategy potential by land use to year 2030 .

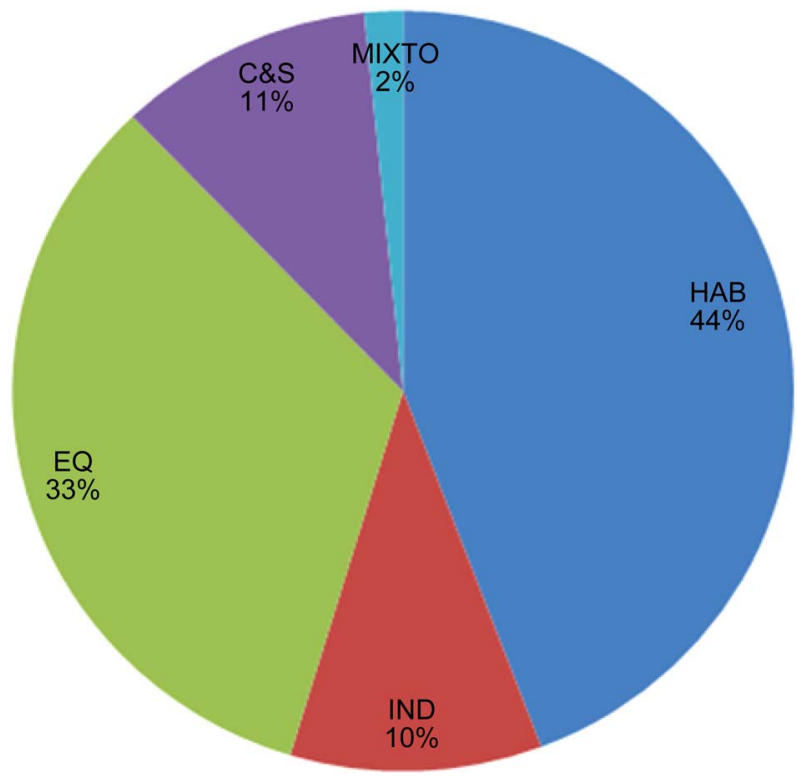

Figure 10. Green space strategy potential by land use to year 2030 .

\section{Conclusions}

The results show the convenience of using dynamic modeling as a tool applied to urban planning with a focus towards mitigation and adaptation to climate change. Regarding the implementation of mitigation strategies against UHI, the results show that it is more effective to apply across the city, and the highest effects are obtained in the medium term applying the $50 \%$ of the mitigation potential. Cool and green roofs in housing are the most effective due the surface representing the city, followed by cool pavements and green spaces. However, it is necessary to evaluate the advantages of continuing with the same density patterns as established by the urban development plan. 
The results also contribute to promoting the use of strategies in design, urbanization and building, in addition to providing evidence to support changes to the processes of urban planning, as well as existing regulations of construction and urbanization. As noted, the materials used in the construction of roofs and pavements play an important role in relation to the increase of urban temperature. Therefore, it is important to focus on strategies that modify the surface characteristics of the urban fabric, which offers the greatest potential for mitigating the UHI and updating the urban development policy and the construction regulations, as part of the actions to mitigation and adaptation to climate change.

The local scenario of climate change shows an increase in the maximum average of summer temperature up to $52.8^{\circ} \mathrm{C}$, for year 2080 [11] [32]; this increase will intensify the UHI if not consider the strategies as part of the urban development policy. An additional advantage of the proposed method is the ability to resize the model and add additional variables related to the urban environment, this allows identifying other relations between the UHI and other morphological or socio-economic characteristics, thus achieving a framework adaptive research. In conclusion, the results contribute to establishing land use policies and building typologies; also provide inputs for climate vulnerability assessing of the city, contributing to the process of adaptation to climate change in cities with arid climate extreme.

\section{References}

[1] Oke, T.R. (2009) Boundary Layer Climates. 2nd Edition, Routledge, New York.

[2] Tan, J.G., Zheng, Y.F., Xu, T., Guo, C.Y., Li, L.P., Song, G.X., Zhen, X.R., Yuan, D., Kalkstein, A.J., Li, F.R. and Chen, H. (2010) The Urban Heat Island and Its Impact on Heat Waves and Human Health in Shanghai. International Journal of Biometeorology, 54, 75-84. https://doi.org/10.1007/s00484-009-0256-x

[3] Arnfield, J. (2003) Two Decades of Urban Climate Research: A Review of Turbulence, Exchanges of Energy and Water and the Urban Heat Island. International Journal of Climatology, 23, 1-26.

[4] Pearlmutter, D., Berliner, P.Y. and Shaviv, E. (2006) Current Research and Challenges in Urban Climate Research in Arid Regions. In: Grimmond, S. and Lindqvist, S., Eds., Proceedings of ICUC 06-6th International Conference on Urban Climate, Goteborg, Suecia, 12-16 June 2006, 28-31.

[5] Stephen, H., Palmer, C., Ahmad, S. and Black, A. (2013) Development of Heat Island Dataset for Las Vegas Urban Canopy City Green Analysis. University of Nevada Las Vegas, Las Vegas.

http://forestry.nv.gov/wp-content/uploads/2013/06/UHI_LasVegas_Final_Report.p df

[6] Chow, W.T.L., Brennan, D. and Brazel, A.J. (2012). Urban Heat Island Research in Phoenix, Arizona: Theoretical Contributions and Policy Applications. Bulletin of American Meteorological Society, 93, 517-530. https://doi.org/10.1175/BAMS-D-11-00011.1

[7] City of Las Vegas (2010) Summary Report Urban Heat Island Effect. City of Las Vegas, Office of Sustainability. http://www.lasvegasnevada.gov/files/UHI_Report_2010-2.pdf 
[8] Hawkins, T.W., Brazel, A.J., Stefanov, W.L., Bigler, W. and Saffell, E.M. (2004) The Role of Rural Variability in Urban Heat Island Determination for Phoenix, Arizona. Journal of Applied Meteorology and Climatology, 43, 476-486. https://doi.org/10.1175/1520-0450(2004)043<0476:TRORVI>2.0.CO;2

[9] Baker, L., Brazel, A.J., Selover, N., Martin, C., McIntyri, N., Steiner, F., Nelson, A. and Musacchio, Y.L. (2002) Urbanization and Warming of Phoenix (Arizona, USA): Impacts, Feedbacks and Mitigation. Urban Ecosystems, 6, 183-203. https://doi.org/10.1023/A:1026101528700

[10] Comrie, A.C. (2000) Mapping a Wind-Modified Urban Heat Island in Tucson, Arizona (with Comments on Integrating Research and Undergraduate Learning). $\mathrm{Bu}$ lletin of the American Meteorological Society, 81, 2417-2431. https://doi.org/10.1175/1520-0477(2000)081<2417:MAWMUH>2.3.CO;2

[11] Camargo-Bravo, A. and Garcia-Cueto, R.O. (2012) Evaluation of Two Models Downscaling Generation Climate Change Scenarios in the Mexicali Valley in Mexico. Journal of Information Technology, 23, 11-20.

[12] García Cueto, O.R., Tejeda, M.A. and Bojórquez, M.G. (2009) Urbanization Effects upon the Air Temperature in Mexicali B.C., México. Atmosphere, 22, 349-365.

[13] García Cueto, O.R., Jáureguio, E.O., Toudert, D. and Tejeda-Martínez, A. (2007) Detection of the Urban Heat Island in Mexicali B.C., Mexico and Its Relationship with Land Use. Atmósfera, 20, 111-131.

[14] Akbari, H. (2009) Cooling Our Communities. A Guidebook on Tree Planting and Light-Colored Surfacing. Lawrence Berkeley National Laboratory, Berkeley. http://escholarship.org/uc/item/98z8p10x

[15] Ramos, G. and José, M. (2011) Strategic Environmental Management of Air in the Mexicali-Imperial Border. Gestión estratégica ambiental del aire en la frontera Mexicali-Imperial. Estudios Fronterizos, 12, 35-73.

[16] Elva, C. and Rojas, I. (2009) Air Quality and Incorporation into Urban Planning: Mexicali, Baja California, Mexico. Calidad del aire y su incorporación en la planeación urbana: Mexicali, Baja California, México. Estudios Fronterizos, 10, 79 102.

[17] Secretaria de Protección al Ambiente del Estado de Baja California (SPA) (2007) Greenhouse Gases Emissions Inventory of Baja California. Inventario de Emisiones de Gases de Efecto Invernadero del Estado de Baja California. Centro Mario Molina para Estudios Estratégicos sobre Energía y Medio Ambiente. http://www2.ine.gob.mx/sistemas/peacc/descargas/bc_igei_2005_vf.pdf

[18] Pena-Salmon, C.A. and Rojas-Caldelas, R.I. (2009) Methodology for Planning Urban Green Areas: The Case of Mexicali, Baja California, México. WIT Transactions on Ecology and the Environment, 120, 33-41. https://doi.org/10.2495/SDP090041

[19] Toudert, D. (1996) Urban Linkages with Climate Intrarregional and Study of Heat Islands in the City of Mexicali. La Articulación Urbana con el Clima Intraregional y el Estudio de las Islas de Calor en la Ciudad de Mexicali. Revista Calafia, 8, 29-35.

[20] Scott, K.I., Simpson, J.R. and McPherson, E.G. (1999) Effects of Tree Cover on Parking Lot Microclimate and Vehicle Emissions. Journal of Arboriculture, 25, 129-142.

[21] Spronken-Smith, R.A. and Oke, T.R. (1998) The Thermal Regime of Urban Parks in Two Cities with Different Summer Climates. International Journal of Remote Sensing, 19, 2085-2104. https://doi.org/10.1080/014311698214884

[22] Villanueva, J., Venegas, F.R. and García, O.R. (2008) Urban Heat Island: Urban Analysis, Assessment and Measuring Mitigation in Cities of Extreme Dry Weather. The 3rd International C.E.U. Congress: Climate Change and Urban Design, Oslo, 14-16 September 2008, 180-190. 
[23] Lynn, B.H., Carlson, T.N., Rosenzweig, C., Goldberg, R., Druyan, L., Cox, J., Gaffin, S., Parshall, L. and Civerolo, K. (2009) A Modification to the NOAH LSM to Simulate Heat Mitigation Strategies in the New York City Metropolitan Area. Journal of Applied Meteorology and Climatology, 48, 199-216. https://doi.org/10.1175/2008JAMC1774.1

[24] Meredith, H.A. (2004) Designing with Climate: Using Parking Lots to Mitigate Urban Climate. Tesis de maestría en arquitectura del paisaje. Departamento de paisaje y estudios urbanos. Universidad Estatal y el Instituto Politécnico de Virginia. Estados Unidos.

[25] Taha, H., Douglas, S. and Haney, J. (1997) Mesoscale Meteorological and Air Quality Impacts of Increased Urban Albedo and Vegetation. Energy and Building, 25, 169-177. https://doi.org/10.1016/S0378-7788(96)01006-7

[26] Pomerantz, M., Pon, B., Akbari, H. and Chang, S.-C. (2002) The Effect of Pavements' Temperatures on Air Temperatures in Large Cities. Lawrence Berkeley National Laboratory Report LBNL-43442, Berkeley.

[27] Akram, R. and Bryan, H. (2010) Optimizing the Effect of Vegetation for Pedestrian Thermal Comfort and Urban Heat Island Mitigation in a Hot Arid Urban Environment. 4th National Conference of IBPSA-USA, New York, 11-13 August 2010, 230 237.

[28] POE (2007) Programa de Desarrollo Urbano de Centro de Población Mexicali, B.C. 2025. Periódico Oficial del Gobierno del Estado de Baja California. Tomo CXIV, Número 10.

[29] Osvaldo, L.C. (2009) Urban Integration of the City of Mexicali. Ponencia: Grado de Integración Urbana de la Ciudad de Mexicali. Primer congreso de egresados del 9 al 11 de septiembre de 2009, Colegio de la Frontera Norte.

[30] Rojas Caldelas, R.I. (2000) Urban Environmental Assessment: Methodological Proposal and Application to a Case Study, Mexicali, Baja California. Evaluación Ambiental Urbana: Propuesta Metodológica y aplicación a un estudio de caso, Mexicali, Baja California. Universidad Autónoma de México, México, D.F.

[31] Perico-Agudelo, D. (2009) The Public Space of the City: An Approach from the Study of Their Microclimatic Characteristics. El espacio público de la ciudad: Una aproximación desde el estudio de sus características microclimáticas. Cuadernos de Vivienda y Urbanismo, 2, 278-301.

[32] PEACCBC (2010) Baja California Action Plan against Climate Change. Programa Estatal de Acción ante Cambio Climático para Baja California. Escenarios Climáticos Locales. http://peac-bc.cicese.mx/

[33] Torok, S.J., Morris, C.J.G., Skinner, C. and Plummer, N. (2001) Urban Heat Island Features of Southeast Australian Towns. Australian Meteorological Magazine, 50, 1 13. 
Submit or recommend next manuscript to SCIRP and we will provide best service for you:

Accepting pre-submission inquiries through Email, Facebook, LinkedIn, Twitter, etc. A wide selection of journals (inclusive of 9 subjects, more than 200 journals)

Providing 24-hour high-quality service

User-friendly online submission system

Fair and swift peer-review system

Efficient typesetting and proofreading procedure

Display of the result of downloads and visits, as well as the number of cited articles Maximum dissemination of your research work

Submit your manuscript at: http://papersubmission.scirp.org/

Or contact ajcc@scirp.org 